\title{
Low-latitude paleosecular variation and the time-averaged field during the late Pliocene and Quaternary-Paleomagnetic study of the Michoacan-Guanajuato volcanic field, Central Mexico
}

\author{
G. Conte-Fasano $^{1 *}$, J. Urrutia-Fucugauchi ${ }^{1}$, A. Goguitchaichvili ${ }^{1,2 \dagger}$, and J. Morales-Contreras ${ }^{1}$ \\ ${ }^{1}$ Laboratorio de Paleomagnetismo y Geofisica Nuclear, Instituto de Geofisica, Universidad Nacional Autonoma de Mexico, \\ Ciudad Universitaria, 04510 México D.F., Mexico \\ ${ }^{2}$ Laboratorio Interinstitucional de Magnetismo Natural Instituto de Geofisica, Universidad Nacional Autonoma \\ de Mexico, Coeneo, Michoacán, Mexico
}

(Received December 2, 2005; Revised June 12, 2006; Accepted July 13, 2006; Online published November 8, 2006)

\begin{abstract}
We report paleomagnetic, rock magnetic, and paleointensity studies for 24 volcanic lava flows from the Michoacan-Guanajuato volcanic field (MGVF), erupted between 2.27 Ma to present according to available radiometric ages and historic records. The MGVF located in the central-western sector of the Plio-Quaternary TransMexican volcanic belt is mainly composed by cinder cones and shield volcanoes. Rock magnetic experiments show remanence is carried in most cases by Ti-poor titanomagnetites, resulting from oxy-exsolution of original titanomagnetites during flow cooling. Unblocking temperature spectra and high coercivities point to "small" pseudo-single domain grains for the titanomagnetites. Single component, linear vector plots are obtained after alternating field and thermal demagnetization. Seven flows yield reverse polarity magnetization while sixteen flows are normally magnetized. The overall mean paleodirection obtained (with 14 flows normal and 6 flows reverse) is $\mathrm{I}=28.4^{\circ}, \mathrm{D}=357.9^{\circ}, \mathrm{k}=21, \alpha_{95}=7.3^{\circ}$, with a paleomagnetic pole position of $P_{\text {lat }}=85.7^{\circ}, P_{\text {long }}=104.5^{\circ}, \mathrm{K}=27$, $\mathrm{A}_{95}=6.4^{\circ}$. The paleodirection is undistinguishable from expected Plio-Quaternary paleodirections derived from reference poles for the North American polar wander curve, and previously reported paleodirections for central Mexico. Paleointensity experiments give high quality results for only twelve samples from two flows with mean values of 7.3 and $8.1 \times 10^{22} \mathrm{Am}^{2}$, which are close to present geomagnetic field intensity. The combination of new MGVF directional results with currently available paleomagnetic data from central Mexico yield angular dispersion estimates of $S_{F}=15.4$ with $S_{U}=19.6$ and $S_{L}=12.7$, which are in agreement with the latitude-dependent PSV model of McFadden et al. $(1988,1991)$ for the last $5 \mathrm{Ma}$, and show no significant inclination anomaly.
\end{abstract}

Key words: Paleomagnetism, geomagnetic secular variation, paleointensity, Plio-Quaternary, Central Mexico.

\section{Introduction}

Study of the spatial and temporal variations of the Earth's magnetic field and the nature of the time-averaged field have remained central topics for paleomagnetic research. These studies permit investigation of the internal geodynamo processes that generate the field, and tectonic and stratigraphic applications of paleomagnetic data. The geocentric axial dipole (GAD) hypothesis states that average of paleomagnetic directions observed in a given locality over a long enough interval results in a GAD field. The length of the interval is assumed dependent of the characteristics of the temporal variations of the geomagnetic field. Study of the spatial and temporal variations of the field and the nature of the time-averaged field have benefited from the accumulation of reliable paleomagnetic data from differ-

*Also at: Instituto de Investigaciones Antropologicas, UNAM, Ciudad Universitaria, 04510 México, D.F., Mexico.

${ }^{\dagger}$ Also at: Departamento de Geologia y Mineralogía, Universidad Michoacana San Nicolas de Hidalgo.

Copyright (c) The Society of Geomagnetism and Earth, Planetary and Space Sciences (SGEPSS); The Seismological Society of Japan; The Volcanological Society of Japan; The Geodetic Society of Japan; The Japanese Society for Planetary Sciences; TERRAPUB. ent regions and development of new modeling and inversion techniques. However, global data coverage remains unevenly distributed in space and time, and more data are needed to document the field characteristics and to constrain models, particularly for low-latitude regions. Furthermore, the database of paleomagnetic directions is far more complete than that available for paleointensities, which makes modeling of the total vectorial field a difficult problem.

Paleomagnetic studies of the Plio-Quaternary volcanic sequences have investigated the paleosecular variation (PSV) characteristics for central Mexico, with contrasting conclusions in regard to the amount of paleosecular variation as estimated by the angular dispersion of virtual geomagnetic poles (VGP) (e.g., Steele, 1985; Herrero-Bervera et al., 1986; Bohnel et al., 1990; Urrutia-Fucugauchi, 1995, 1997; Gonzalez et al., 1997; Bohnel and Molina-Garza, 2002). Comparison of the PSV determinations with PSV models of latitudinal variation of VGP angular dispersion in the past have alternatively suggested that central Mexico is/is not part of the low non-dipole field for the Pacific Ocean region. The study of the Pacific low non-dipole window and the nature of regional inclination anomalies remains an important aspect of paleomagnetic research (e.g., 




Fig. 1. Main volcanic provinces of Mexico: 1) Eastern Alkaline Province; 2) Sierra Madre Occidental; 3) Baja California Province; 4). Trans-Mexican volcanic belt. Inset of the Michocán-Guanajuato volcanic field (MGVF) is shown as a rectangle. (modified from Ban et al., 1992)

Doell and Cox, 1971, 1972; McElhinny et al., 1996; Elmaleh et al., 2001).

In the present study, we have studied 24 monogenetic volcanic centers of the Michoacan-Guanajuato volcanic field (Fig. 1), erupted between 2.27 Ma to present according to $\mathrm{K}-\mathrm{Ar}$, Ar-Ar and radiocarbon radiometric ages. In addition, we examined published data and constructed a new updated paleomagnetic database for central Mexico. One of the objectives of this study is to estimate the paleosecular variation of geomagnetic field for central Mexico. Additionally, we use the Thellier paleointensity method in selected samples to provide new data on the full vector geomagnetic variation during the Plio-Quaternary.

\section{Geological Setting and Sampling}

The Michoacan-Guanajuato volcanic field is located at the west-central part of the Trans-Mexican volcanic belt (TMVB) (Fig. 1). The TMVB is related to Neogene subduction of the Cocos and Rivera plates beneath the southwestern margin of the North American plate. The basal units of the TMVB are late Miocene, and in the western sector cover the Eocene to early Miocene Sierra Madre Occidental silicious volcanic province. TMVB is a $20-150 \mathrm{~km}$ wide, 1,000 km long and about 1000-2000 $\mathrm{m}$ high volcanic plateau, which roughly extends from the Pacific Ocean to the Gulf of Mexico; it includes high stratovolcanoes (e.g. Popocatepetl, Colima, Pico de Orizaba), shield volcanoes (e.g., Cerro Paracho, Cerro Culiacan, Cerro Yahuarato), monogenetic cinder cone fields (e.g., MGVF, Chichinautzin) and silicic calderas (e.g., Amealco). Unlike typical trench-arc systems, TMVB is not parallel to the Middle America trench, but forms an angle of about $20^{\circ}$ with respect to the trench (Molnar and Sykes, 1969; UrrutiaFucugauchi and del Castillo, 1977) (Fig. 1). Geochemical studies document a province of both calc-alkaline and alkaline composition, which accounts for the occurrence of dacitic, andesitic and basaltic rocks. The construction of andesitic centers in the western part of the TMVB that lie

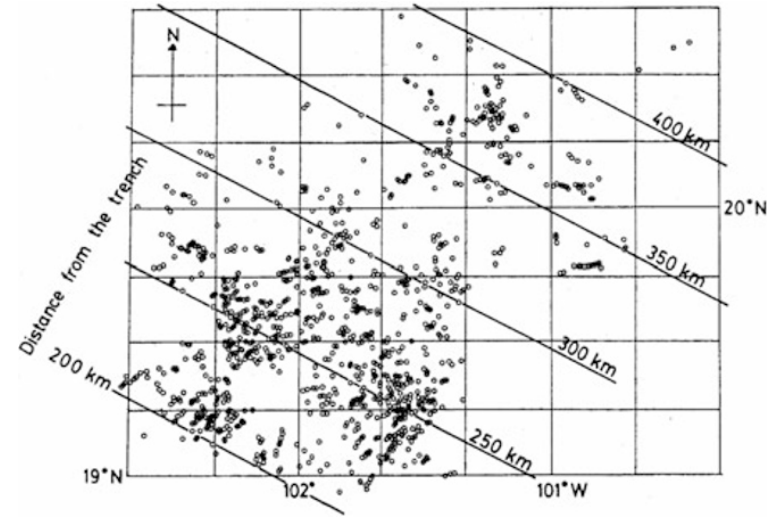

Fig. 2. Distribution of small-sized monogenetic volcanoes (circles) in the Michoacán-Guanajuato volcanic field. The majority of cinder cones (75\%) are distributed between $200 \mathrm{~km}$ and $300 \mathrm{~km}$ of distance from Middle America Trench (modified from Hasenaka and Carmichael, 1985).

above the subducted portion of the Rivera plate started between 0.6 and 0.2 Ma. However, in the central and eastern parts of the arc, where the Cocos plate is subducting, edification of the andesite-dacite volcanoes began considerably earlier, at approximately 1.7 Ma (Nixon et al., 1987).

The western TMVB sector is characterized by three rift systems: 1) Tepic-Zacoalco graben trending NW-SE, 2) Colima graben which has N-S orientation, and 3) Chapala rift trending E-W (Fig. 1). The Michoacan-Guanajuato volcanic field is localized on the Chapala Lake eastern sector, which constitutes the axis of Chapala rift. The geographic boundaries of the MGVF are delineated by the $18^{\circ} 45^{\prime} \mathrm{N}$ and $20^{\circ} 15^{\prime} \mathrm{N}$ parallels and the $100^{\circ} 25^{\prime} \mathrm{W}$ and $100^{\circ} 45^{\prime} \mathrm{W}$ meridians. The MGVF, with an area of $40,000 \mathrm{~km}^{2}$, contains over 1,000 small-sized monogenetic volcanoes including: cinder cones $(90 \%)$, maars, tuff rings, lava domes and lava flows with hidden vents; all centers have a character predominant calc-alkaline but alkaline and transitional rocks are also found; all have a wide variation of silica content from $47 \%$ to $70 \%$ with olivine basalt and basalt-andesite rocks (Hasenaka, 1994; Hasenaka et al., 1994). Generally speaking, alkaline cinder cones are older and located towards the northern sector of MGVF.

The cinder cones are situated between $200 \mathrm{~km}$ and 440 $\mathrm{km}$ from Middle America trench, where the majority of them $(75 \%)$ are distributed between $200 \mathrm{~km}$ and $300 \mathrm{~km}$ of distance from the trench (Fig. 2). The median cinder cone has a height of $90 \mathrm{~m}$, a basal diameter of $800 \mathrm{~m}$, a crater diameter of $230 \mathrm{~m}$, and a volume of $0.021 \mathrm{~km}^{3}$. In general, cinder and lava cones are active for a short period of time, approximately by few months to twenty years and rarely the activity restart. Two cinder cones have been born in historic times; the Paricutin in 1943-1952 and the Jorullo in 1759-1774.

In addition to the small-sized centers, there are about 300 medium-sized volcanoes that have mainly erupted calcalkaline andesites with the majority of lavas falling in the $\mathrm{SiO}_{2}$ range between of the $55 \%$ to $61 \%$ (Hasenaka and Carmichael, 1985). This medium-sized volcanoes represent principally Icelandic-type shields, with slopes between $5^{\circ}$ 
Table 1. Site mean paleodirections of cleaned remanence and corresponding VGP positions for MGVF volcanics. $N$ : number of treated samples, $n$ : number of specimens used for calculation, Dec: Declination, Inc: Inclination, $\mathrm{k}$ and $\alpha_{95}$ : precision parameter and radius of $95 \%$ confidence cone of Fisher statistics, $P_{\text {lat }} / P_{\text {long }}$ : Latitude/Longitude of VGP position. Sites are listed in stratigraphic order.

\begin{tabular}{|c|c|c|c|c|c|c|c|c|c|c|c|c|}
\hline \multirow[t]{2}{*}{ Site } & \multicolumn{2}{|c|}{ Coordinates } & \multirow[t]{2}{*}{ Age } & \multirow[t]{2}{*}{$n / N$} & \multirow[t]{2}{*}{ Dec. $\left({ }^{\circ}\right)$} & \multirow[t]{2}{*}{ Inc. $\left(^{\circ}\right)$} & \multirow[t]{2}{*}{$\alpha_{95}\left(^{\circ}\right)$} & \multirow[t]{2}{*}{$k$} & \multirow[t]{2}{*}{$P_{\text {lat }}$} & \multirow[t]{2}{*}{$P_{\text {long }}$} & \multirow[t]{2}{*}{ Pol. } & \multirow{2}{*}{$\begin{array}{l}\text { Ref. } \\
\text { Age }\end{array}$} \\
\hline & $\left({ }^{\circ} \mathrm{N}\right)$ & $\left({ }^{\circ} \mathrm{W}\right)$ & & & & & & & & & & \\
\hline 19-Paricutin* & 19.53 & 102.25 & 1943-1945 AD & $7 / 9$ & 47.3 & 27.5 & 7.3 & 70 & 63.4 & 322.9 & $\mathrm{~N}$ & 2 \\
\hline 24-El Jorullo & 19.00 & 101.75 & 1759-1774 AD & $7 / 8$ & 8.9 & 55.6 & 3.8 & 212 & 71.2 & 281.1 & $\mathrm{~N}$ & 2 \\
\hline 21-El Jabalí & 19.42 & 102.13 & $3.83 \pm 0.15 \mathrm{Ka}$ & $6 / 10$ & 349.5 & 26.1 & 2.2 & 898 & 78.4 & 140.1 & $\mathrm{~N}$ & 2 \\
\hline 18-El Metate & 19.57 & 102.02 & $4.7 \pm 0.2 \mathrm{Ka}$ & $8 / 11$ & 16.1 & 24.6 & 1.9 & 816 & 73.2 & 8.9 & $\mathrm{~N}$ & 2 \\
\hline 15-La Taza & 19.53 & 101.69 & $8.43 \pm 0.33 \mathrm{Ka}$ & $10 / 10$ & 336.6 & 30.3 & 4.2 & 134 & 67.6 & 163.7 & $\mathrm{~N}$ & 2 \\
\hline 11-La Mina & 19.70 & 101.40 & $17.17 \pm 0.43 \mathrm{Ka}$ & $8 / 8$ & 345.5 & 4.6 & 2.2 & 633 & 67.5 & 119.6 & $\mathrm{~N}$ & 2 \\
\hline 14-El Estribo* & 19.52 & 101.66 & $25 \pm 4 \mathrm{Ka}$ & $5 / 7$ & 303.9 & 29.6 & 5.9 & 170 & 36.7 & 173.9 & $\mathrm{~N}$ & 4 \\
\hline 8-El Pueblito & 19.82 & 101.92 & $29 \pm 3.3 \mathrm{Ka}$ & $8 / 9$ & 21.6 & 33.7 & 3.2 & 306 & 69.6 & 348.4 & $\mathrm{~N}$ & 2 \\
\hline 16-Cerro Cainjuata & 19.66 & 102.03 & $<40 \mathrm{Ka}$ & $11 / 11$ & 6.8 & 40.6 & 2.5 & 346 & 82.7 & 317.4 & $\mathrm{~N}$ & 4 \\
\hline 22-Cerro Urujuato & 19.00 & 102.20 & $<40 \mathrm{Ka}$ & $13 / 13$ & 337.5 & 16.5 & 2.1 & 403 & 65.8 & 144.9 & $\mathrm{~N}$ & 4 \\
\hline 2-Cerro Gordo & 20.40 & 100.97 & $>40 \mathrm{Ka}$ (Brunhes) & $8 / 12$ & 5.3 & 33.0 & 5.9 & 88 & 84.4 & 13.6 & $\mathrm{~N}$ & 4 \\
\hline 17-Cerro Paracho & 19.62 & 102.07 & $60 \pm 10 \mathrm{Ka}$ & $8 / 10$ & 15.7 & 23.3 & 3.8 & 211 & 73.2 & 11.9 & $\mathrm{~N}$ & 1 \\
\hline 7-El Picacho & 19.82 & 101.95 & $170 \pm 30 \mathrm{Ka}$ & $9 / 10$ & 349.5 & 17.3 & 4.4 & 140 & 75.0 & 122.4 & $\mathrm{~N}$ & 1 \\
\hline 20-El Pelon & 19.30 & 101.92 & $370 \pm 50 \mathrm{Ka}$ & $7 / 11$ & 347.8 & 24.2 & 7.7 & 63 & 76.5 & 140.4 & $\mathrm{~N}$ & 2 \\
\hline 23-Buenavista Tomatlan & 19.14 & 102.55 & $540 \pm 80 \mathrm{Ka}$ & $12 / 12$ & 2.61 & 17.2 & 2.5 & 292 & 79.3 & 63.4 & $\mathrm{~N}$ & 1 \\
\hline 13-Yahuarato & 19.62 & 101.57 & $540 \pm 70 \mathrm{Ka}$ & $6 / 10$ & 183.5 & -29.4 & 2.2 & 950 & -84.9 & 217.2 & $\mathrm{R}$ & 1 \\
\hline 12-Cerro Sanambo & 19.63 & 101.44 & $870 \pm 50 \mathrm{Ka}$ & $12 / 12$ & 181.3 & -23.0 & 3.3 & 177 & -82.3 & 248.9 & $\mathrm{R}$ & 3 \\
\hline 4-Cerro Camataran* & 20.19 & 101.52 & $1.17 \pm 0.14 \mathrm{Ma}$ & $5 / 13$ & 164.9 & -38.1 & 22.3 & 13 & -75.9 & 355.9 & $\mathrm{R}$ & 1 \\
\hline 5-Cerro Grande & 20.10 & 101.59 & $>40 \mathrm{Ka}$ (Matuyama) & $10 / 12$ & 200.8 & -42.3 & 5.3 & 83 & -70.3 & 151.8 & $\mathrm{R}$ & 4 \\
\hline 10-El Fresno & 19.94 & 101.77 & $>40 \mathrm{Ka}$ (Matuyama) & $8 / 11$ & 182.9 & -3.6 & 2.7 & 430 & -71.6 & 248.7 & $\mathrm{R}$ & 4 \\
\hline 6-Cerro Grande La Piedad & 20.33 & 102.10 & $1.60 \pm 0.10 \mathrm{Ma}$ & $9 / 11$ & 165.9 & -45.1 & 4.7 & 122 & -75.6 & 16.5 & $\mathrm{R}$ & 3 \\
\hline 9-Brinco del Diablo & 19.91 & 101.75 & $1.88 \pm 0.24 \mathrm{Ma}$ & $11 / 12$ & 348.3 & 26.9 & 1.7 & 722 & 77.5 & 143.3 & $\mathrm{~N}$ & 1 \\
\hline 3-Cerro Culiacán & 20.33 & 101.01 & $2.10 \pm 0.24 \mathrm{Ma}$ & $9 / 10$ & 170.7 & -35.6 & 6.6 & 62 & -80.6 & 346.6 & $\mathrm{R}$ & 1 \\
\hline 1-Cerro Grande Cortazar* & 20.40 & 100.88 & $2.27 \pm 0.27 \mathrm{Ma}$ & / & / & / & / & / & / & / & / & 1 \\
\hline Mean & & & & $0-2.10 \mathrm{Ma}$ & 20 & 357.9 & 28.4 & 7.3 & 21 & 85.7 & 104.5 & \\
\hline
\end{tabular}

* Sites not included in calculation of overall mean direction (see text).

(1) Ban et al. (1992); (2) Hasenaka and Carmichael (1985); (3) Nixon et al. (1987); (4) This study.

and $15^{\circ}$, a basal diameter between 3 and $8 \mathrm{~km}$, heights between 300 and $700 \mathrm{~m}$, and volumes between 1 and 10 $\mathrm{km}^{3}$ (Ban et al., 1992). These shield volcanoes, were built during an essentially continuous discharge from a central vent, and thus are monogenetic volcanoes. Therefore, these volcanoes represent an important part of the total magma erupted into the volcanic field. Geomorphologically the lava flows associated to these medium-sized volcanoes are older than those from cinder cones, thus they are possible precursors to the small-sized volcanoes (Hasenaka, 1994). Moreover, there are two stratovolcanos, Volcán Grande and Cerro Tancítaro. The MGVF is different respect to the other parts of the TMVB, which are characterized mainly by composite volcanoes (e.g. Popocatépetl, Nevado de Colima, Pico de Orizaba etc.) with more acid lavas typically.

Six cinder cones have been dated by the ${ }^{14} \mathrm{C}$ method yielding an age between 3,800-29,000 yr BP (Hasenaka and Carmichael, 1985), and other 71 cones seem to correspond to the same time interval (probably within the last $40,000 \mathrm{yr}$ BP) judging from the degree of erosion. These young volcanoes only occur in the southern half of the volcanic field (Hasenaka and Carmichael, 1985, 1987). Ban et al. (1992) have dated eight medium-sized shield volcanoes and one stratovolcano, reporting ages between $0.06 \mathrm{Ma}$ and 2.27 Ma, while Nixon et al. (1987) have dated three shield volcanoes $(0.87-2.60 \mathrm{Ma})$.

The small and medium sized volcanic centers have a similar distribution in time and space. However the mediumsized centers are more frequent in the northern part of the MGVF than small-sized cones, while the cinder cones in the



Fig. 3. Schematic map showing the location of the volcanoes sampled on Michoacán-Guanajuato volcanic field (base map adopted from Ban et al., 1992).

north are older ( $>40,000$ years) than those in the south, suggesting a southern migration of the eruptive activity. This migration has occurred about $1 \mathrm{Ma}$, probably in response to changes in plate motions (Ban et al., 1992; DelgadoGranados et al., 1995)

The MGVF seems well suited for study on the secular variation of the geomagnetic field, because the life of the monogenetic volcanoes is of few years to 20 years, therefore each of them presents a spot reading of the geomagnetic field. Our sampling strategy was largely conditioned by previous stratigraphic and geochronologic studies, we tried to sample only the volcanoes with available radiomet- 

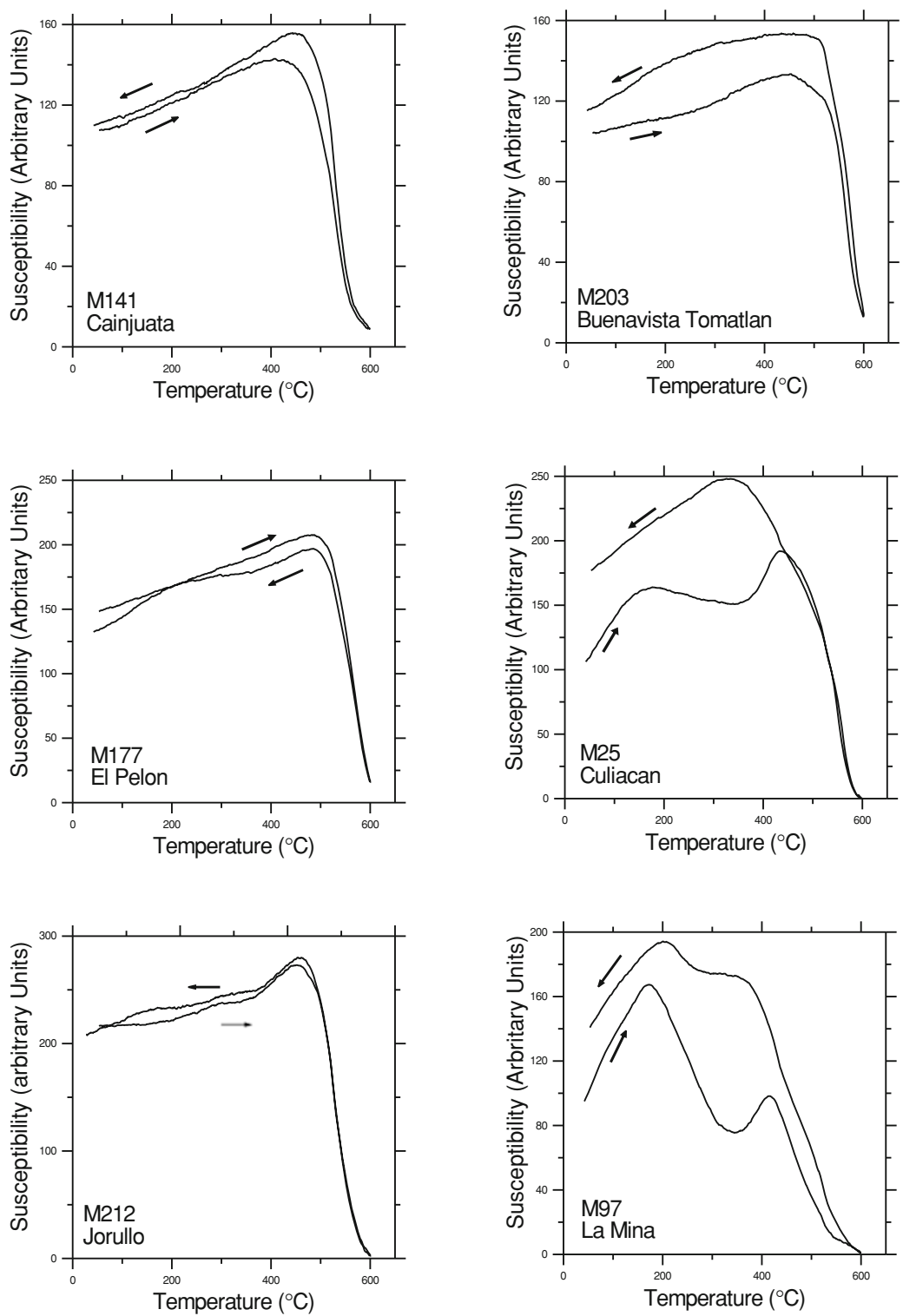

Fig. 4. Temperature-dependent susceptibility curves for representative samples from MGVF. Heating experiments are conducted in air. Arrows indicate the heating and cooling cycle curves.

ric dates (Fig. 3). The names of volcanoes and ages are listed in Table 1. We note that for six volcanic centers only relative ages can be estimated based on relative stratigraphy and field observations. Samples for K-Ar dating from those units have been prepared and are being analyzed (only one yielded analytical results). The new radiometric (K-Ar) date obtained from El Estribo volcanic center yield an age $25 \pm 4$ ka (Herve Guillou, personal communication 2003).

Eight to ten standard paleomagnetic cores were obtained from each site using a portable gasoline-powered drill, and oriented with both magnetic and sun compasses prior to removal. A total of the 230 samples belonging to 24 individual volcanoes were collected (Fig. 3). The cores were later sliced into standard specimen cores $(2.5 \mathrm{~cm}$ diameter, 2.1 $\mathrm{cm}$ high) for the laboratory measurements.

\section{Rock Magnetic Properties}

Rock magnetic measurements were carried out to investigate on the magnetic mineralogy and magnetic car- riers responsible for remanent magnetization and to obtain information about their paleomagnetic stability. These experiments included: a) Measurement of the continuous temperature-dependent susceptibility curves, b) IRM (isothermal remanent magnetization) acquisition experiments and c) Hysteresis loop measurements.

\subsection{Susceptibility vs temperature}

These experiments were carried out using a Bartington susceptibility meter MS-2 equipped with a furnace. The Curie points are determined using Prevot et al.'s (1983) method. One sample per site was heated up to $600^{\circ} \mathrm{C}$ at a rate $10^{\circ} \mathrm{C} / \mathrm{min}$, and then cooled at the same rate (Fig. 4). In most of cases the samples show the presence of a single magnetic/ferrimagnetic phase with Curie temperature $\left(T_{c}\right)$ between $530-580^{\circ} \mathrm{C}$, compatible with the low-Ti titanomagnetite. We note that in some cases, the cooling and heating curves are not reversible and some show a susceptibility increment after cooling (Fig. 4). Few samples show two different thermomagnetic phases during heating (sam- 

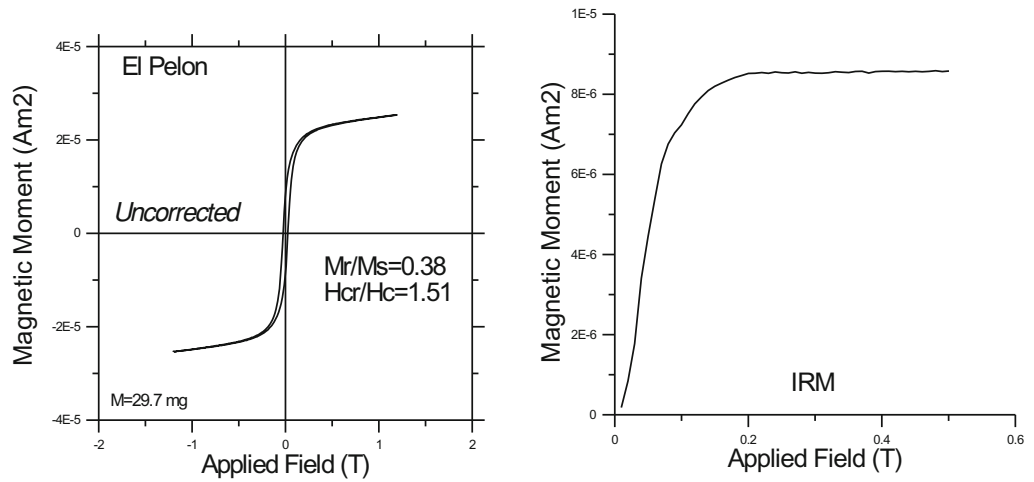

a)
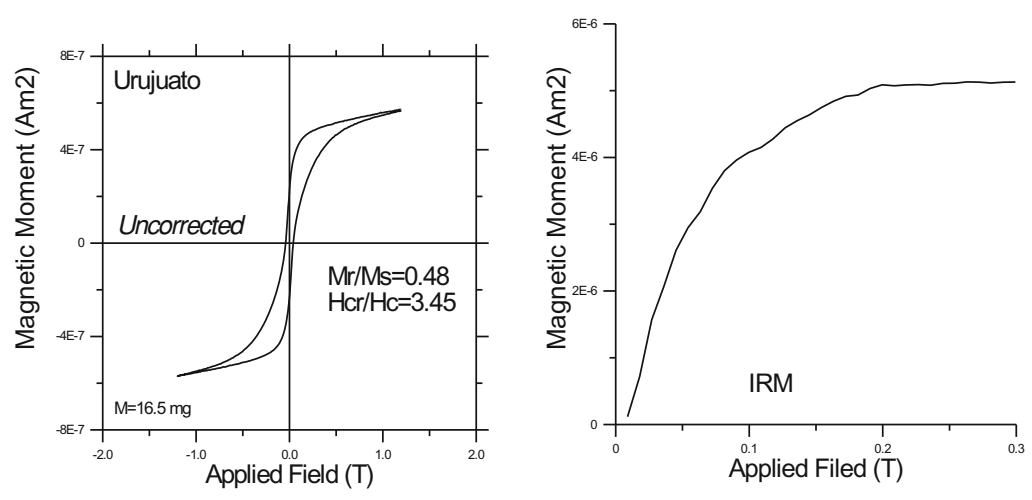

b)

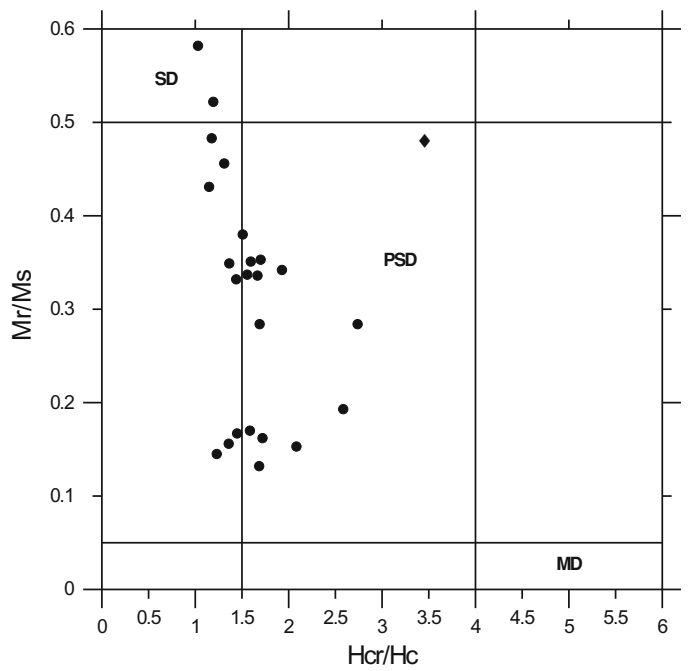

Fig. 5. Examples of magnetic hysteresis measurements for MGVF samples. (a) Typical example of magnetic hysteresis loop (uncorrected for paramagnetic contribution) and associated IRM acquisition curves (see also text for further explanation). (b) Hysteresis parameter ratio plot (Day et al., 1977) with fields for domain fields.

ples M25 and M97). The lower Curie points are about 250$350^{\circ} \mathrm{C}$, and the highest points are about $550-580^{\circ} \mathrm{C}$. The cooling curve shows only a single phase, compatible with magnetite. This behavior may be explained from transformation of titanomaghemites into magnetite during heating of samples in air. In a single case (sample M97), the curve yields evidence of two ferrimagnetic phases during heating and cooling; both Ti-rich and Ti-poor titanomagnetites seem to co-exist in this lava flow.

\subsection{Hysteresis experiments}

Hysteresis measurements at room temperature were carried out on all studied samples using the AGFM 'Micromag' system in fields up to 1.4 Tesla. The hysteresis pa- rameters (saturation remanent magnetization $M_{r}$, saturation magnetization $M_{s}$, and coercive force $H_{c}$ ) were calculated after correction for the paramagnetic contribution. Coercivity of remanent $\left(H_{c r}\right)$ was determined by applying a progressively increasing back-field after saturation. The curves are quite symmetrical (Fig. 5(a)) in almost all cases. Near the origin no potbellied and wasp-waisted behaviors (Tauxe et al., 1996) were detected, which could reflect relatively restricted ranges of grains coercivities. Only exception is site Urujuato that shows typical waspwaisted behavior, and which may reflect coexistence of ferromagnetic phases, most probably the mixture of (titano)magnetite and (titano)hematite with different coerciv- 



Fig. 6. Orthogonal vector plots after stepwise thermal or alternating field demagnetization of representative samples (stratigraphic coordinates). The numbers refer either to the temperatures in ${ }^{\circ} \mathrm{C}$ or to peak alternating fields in $\mathrm{mT}$. o- projections into the horizontal plane, $\mathrm{x}$-projections into the vertical plane.

ities (Tauxe et al., 1996). IRM (Isothermal remanent magnetization) intensity curve indicate, that the saturation is reached in low/moderate fiels of the order of 100-200 mT (sample El Pelon), which suggesting that a spinel phase (titano)magnetite and/or (titano)maghemite is the main remanence carrier. Judging from the ratios of the hysteresis parameters $\left(H_{c r} / H_{c}\right.$ ranges between 0.92 and 3.45 and $M_{r} / M_{s}$ varies from 0.13 to 0.58 ), it seems that all samples fall in the single domain (SD) and pseudo-single-domain (PSD) grain size regions (Day et al., 1977; Dunlop, 2002), probably indicating a mixture of multidomain (MD) and a significant amount of SD grains (Fig. 5(b)).

\section{Paleodirections}

\subsection{Laboratory procedures}

The intensity and direction of natural remanent magnetization (NRM), of 6 to 10 samples from each unit, were measured with a JR-5A spinner magnetometer (sensitivity $\sim 10^{-9} \mathrm{Am}^{2}$ ). Both alternating field (AF) demagnetization up to $100 \mathrm{mT}$ peak fields using a Molspin AF-demagnetizer, and stepwise thermal demagnetization up $575-675^{\circ} \mathrm{C}$ using a non-inductive Schonstedt furnace were carried out to investigate the vectorial composition and stability of NRM.

\subsection{Demagnetizations}

In total, 240 specimens were subjected to stepwise magnetic cleaning. In general single stable paleomagnetic com-

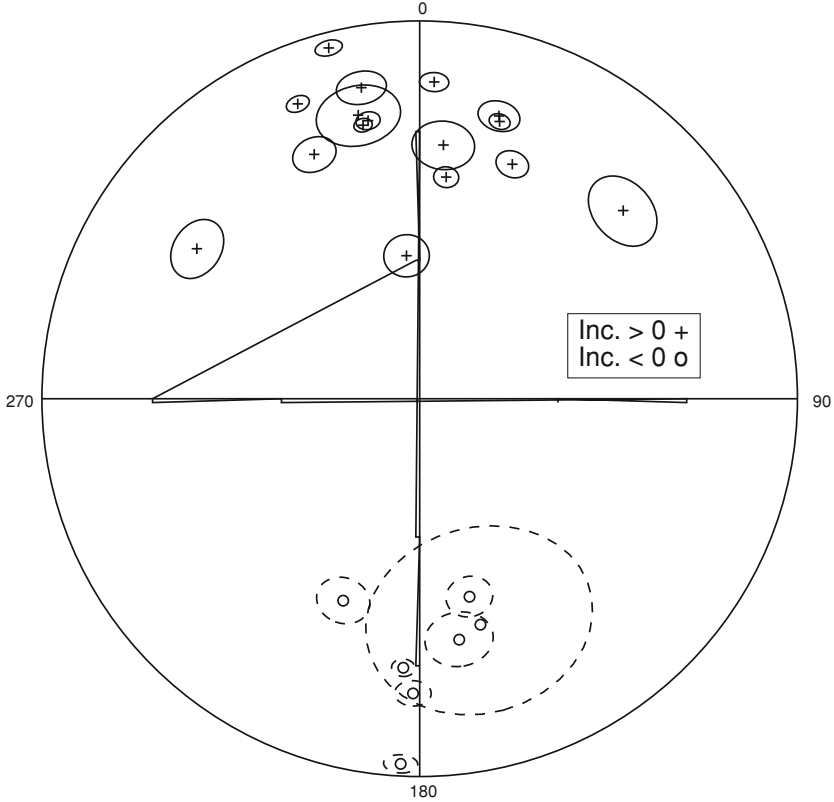

Fig. 7. Equal area projection of site-mean paleodirections for the MGVF, for the normal and reverse polarity units.

ponents were recognized in the samples (Fig. 6). A small secondary component, which is probably a viscous overprint, is sometime present and easily removed after demagnetization to $200-300^{\circ} \mathrm{C}$ or $10-20 \mathrm{mT}$. Few samples (e.g., El Pelon in Fig. 6) show evidence for strong secondary magnetizations, which were removed at about $500^{\circ} \mathrm{C}$. The greater part of remanent magnetization is removed at temperature between 520 and $570^{\circ} \mathrm{C}$, which indicate, once again, that low-Ti titanomagnetites is the main remanence carrier. The median destructive field (MDF) range between (30-40 $\mathrm{mT}$ ) pointing to small PSD grains as remanence carriers (Dunlop and Özdemir, 1997).

\subsection{Directional results}

The characteristic remanent magnetization (ChRM) was determined by the least-squares principal component analysis (PCA) method (Kirschvink, 1980), 4 to 9 points being taken for this determination. The obtained directions are averaged and statistical parameters have been calculated by Fisher distribution (Fisher, 1953). Results for all 24 sites are summarized in Table 1 . Seven sites yielded reverse polarity and 16 sites are of normal polarity (Fig. 7). The betweensite angular dispersion for normal polarity sites is relatively high, with both easterly and westerly declinations. One site (Cerro Grande de Cortazar) was characterized by high NRM intensity (more that several hundred $\mathrm{A} / \mathrm{m}$ ) and scattered NRM direction probably due to the lightning. All samples from this site were rejected for further paleomagnetic analysis.

\section{Paleointensity Determinations}

\subsection{Thellier experiments}

The Thellier method (Thellier and Thellier, 1959) in its modified form (Coe, 1967; Coe et al., 1978) was used in this study. This technique involves heating samples twice at each temperature step: once in a zero magnetic field to re- 

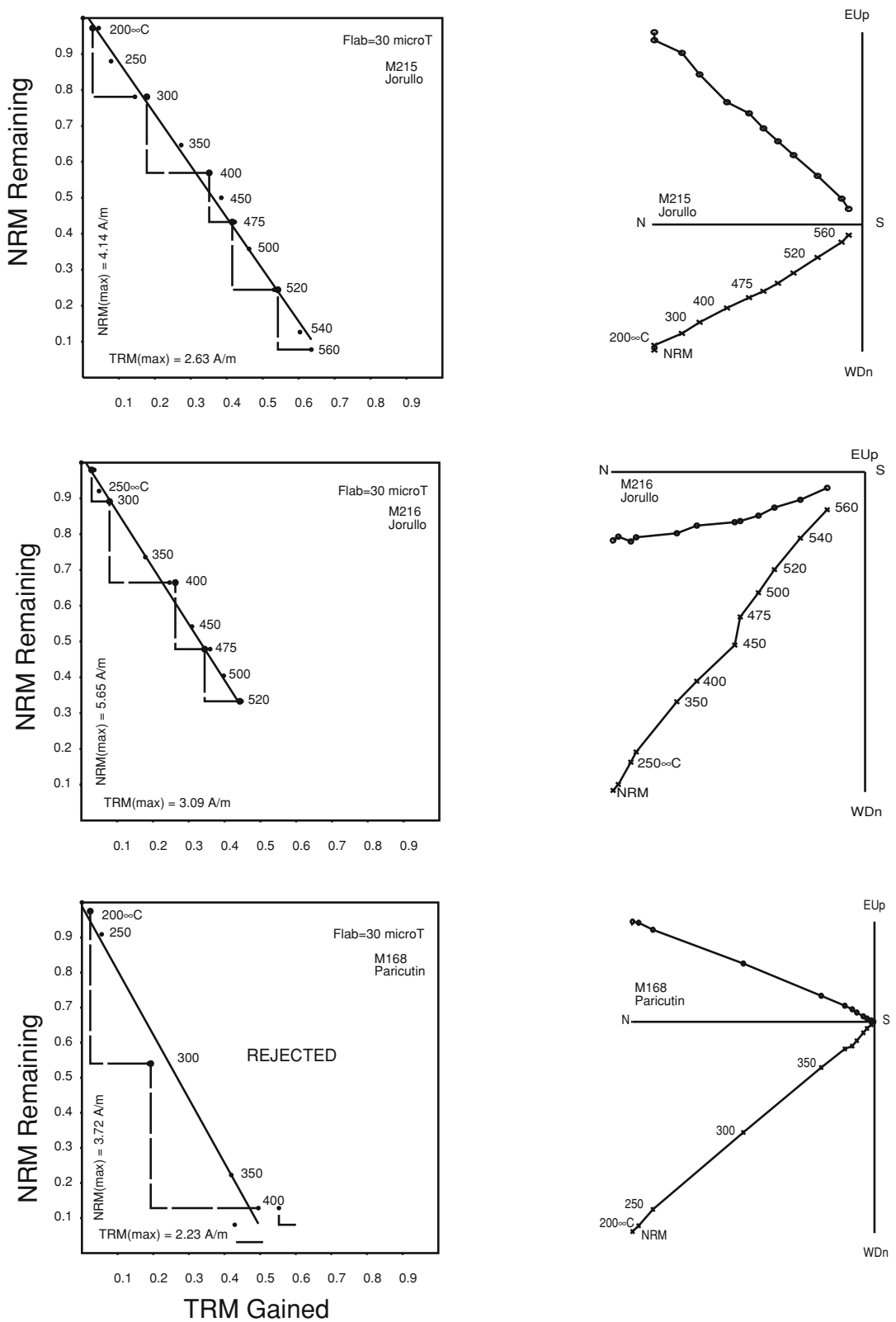

Fig. 8. The representative NRM-TRM plots and associated orthogonal diagrams for MGVF samples. In the orthogonal diagrams we used the same notations as in Fig. 6.

move a portion of NRM and once in a laboratory field to determine the partial thermoremanence (pTRM) gained. The ratio of NRM lost to pTRM gained is proportional to the ancient field. This technique was used in present study to determine absolute geomagnetic paleointensity. The heating and coolings were carried out, using a MDT80 furnace and the laboratory field set to 30 microTesla. Thirteen temperature steps were distributed between room temperature and $580^{\circ} \mathrm{C}$. During the experiment five control heatings (so-called "pTRM" checks) were performed to check the thermal alteration (Coe et al., 1978).

\subsection{Paleointensity results}

Altogether forty-eight samples from six sites (volcanoes) were pre-selected for Thellier paleointensity experiment because of stable one component magnetization accompanied with relatively high MDF values, elevated blocking temper- ature, and reasonably reversible $k-T$ curve. We note that in some cases the heating and cooling $k-T$ curves were not nearly reversible, indicating some degree of mineralogical alteration (Fig. 4). Some typical Arai-Nagata curves (Nagata et al., 1963) are shown in Fig. 8, and the results are given in Table 2. The criteria that we used for individual paleointensity determination are basically similar to those reported by Conte et al. (2004) and can be described as follows. We only accepted determinations that fulfill the following criteria: (1) obtained from at least six NRM-TRM points corresponding to a NRM fraction larger than $1 / 3$, (2) yielding quality factor (Coe et al., 1978) of about 5 or more, and (3) with positive 'pTRM' checks i.e. the deviation of "pTRM" checks was less that $15 \%$ (Table 2).

Finally only twelve samples, from two volcanoes, yield reliable paleointensity estimates. For these samples the 
Table 2. Paleointensity results from MGVF volcanic units, $\mathrm{n}$ is the number of NRM-TRM points used for palaeointensity determination, $\mathrm{T}_{\text {min }}-\mathrm{T}_{\text {max }}$ is the temperature interval used, $f, g$ and $q$ are the fraction of extrapolated NRM used, the gap factor and the quality factor (Coe $e t$ al., 1978) respectively. $F_{E}$ is the paleointensity estimate for an individual specimen, and $\sigma\left(F_{E}\right)$ is its standard error; VDM and VDMe are individual and average virtual dipole moments.

\begin{tabular}{|c|c|c|c|c|c|c|c|c|c|}
\hline Site & Sample & $N$ & $\begin{array}{c}\mathrm{T}_{\min }-\mathrm{T}_{\max } \\
{ }^{\circ} \mathrm{C}\end{array}$ & $f$ & $g$ & $q$ & $\begin{array}{c}F_{E} \pm \sigma\left(F_{E}\right) \\
(\mu \mathrm{T})\end{array}$ & $\begin{array}{c}\text { VDM } \\
10^{22} \mathrm{Am}^{2}\end{array}$ & $\begin{array}{c}\text { VDMe } \\
10^{22} \mathrm{Am}^{2}\end{array}$ \\
\hline Jorullo & M211 & 12 & $20-560$ & 0.88 & 0.88 & 35.20 & $47.4 \pm 1.0$ & 8.56 & $8.1 \pm 1.1$ \\
\hline \multirow{3}{*}{$1759-1754$} & M214 & 11 & $20-560$ & 0.89 & 0.88 & 23.36 & $57.5 \pm 1.9$ & 9.63 & \\
\hline & M215 & 12 & $20-560$ & 0.90 & 0.90 & 28.08 & $43.2 \pm 1.2$ & 6.35 & \\
\hline & M216 & 10 & $20-520$ & 0.66 & 0.86 & 28.60 & $45.1 \pm 0.9$ & 8.18 & \\
\hline Cainjuata & M138 & 12 & $20-560$ & 0.99 & 0.89 & 15.43 & $31.7 \pm 1.8$ & 6.64 & $7.3 \pm 0.6$ \\
\hline \multirow[t]{4}{*}{$<40 \mathrm{Kyr}$} & M139 & 12 & $20-560$ & 0.94 & 0.88 & 15.94 & $29.7 \pm 1.5$ & 6.66 & \\
\hline & M140 & 12 & $20-560$ & 0.89 & 0.86 & 15.94 & $37.7 \pm 1.8$ & 8.2 & \\
\hline & M141 & 12 & $20-560$ & 0.97 & 0.88 & 18.11 & $37.5 \pm 1.7$ & 7.78 & \\
\hline & M142 & 10 & $20-560$ & 0.91 & 0.82 & 12.25 & $35.9 \pm 2.2$ & 7.59 & \\
\hline
\end{tabular}

fraction of NRM $\mathrm{f}$ used for paleointensity determination ranges between $(0.66-0.99)$ and the quality factor $q$ from (12.3-61.4) generally greater than 5. Moreover, the NRM end points, obtained from the Thellier experiments at each step, is reasonably linear and point to the origin (Fig. 8, right side); no deviation of the direction NRM left toward the applied laboratory field was observed. The remaining samples have been rejected on basis of typical "concaveup" behavior (Dunlop and Özdemir, 1997).

\section{Main Results and Discussion}

We consider the characteristic paleomagnetic directions determined for the Michoacan-Guanajuato volcanics to be of primary origin. This is supported by the occurrence of both normal and reversed polarities and absence of secondary magnetizations with linear vector plots after thermal and AF demagnetization. In addition, thermomagnetic curves show that the remanence is carried in most cases by Ti-poor titanomagnetite, resulting of oxi-exsolution of original titanomagnetite during the initial flow cooling, which most probably indicates thermoremanent origin of a primary magnetization. Moreover, unblocking temperature spectra and relatively high coercivity point to 'small' pseudo-single domain magnetic structure grains as responsible for remanent magnetization. Single-component, linear demagnetization plots were observed for most samples.

The mean paleodirection obtained in this study is $\mathrm{I}=28.4^{\circ}, \mathrm{D}=357.9^{\circ}, k=21, \alpha_{95}=7.3^{\circ}$, which corresponds to the mean paleomagnetic pole position $P_{\text {lat }}=85.7^{\circ}$, $P_{\text {long }}=104.5^{\circ}, \mathrm{K}=27, \mathrm{~A}_{95}=6.4^{\circ}$ (Table 1, 4). These directions are practically undistinguishable from the expected Plio-Quaternary paleodirections, as derived from reference poles for the North American polar wander curve (Besse and Courtillot, 2002) and in agreement with previously reported directions from central Mexico (Alva-Valdivia et al., 2001; Morales et al., 2001; Urrutia-Fucugauchi, 1995, 1997; Herrero-Bervera et al., 1986). Absolute paleointensities, obtained from only two sites (twelve samples), yield values close to the present geomagnetic field strength (Table 2). The Thellier and Thellier (1959) method of geomagnetic absolute intensity determination, which is considered the most reliable one, imposes many restrictions on the choice of samples that can be used for a successful determination (Kosterov and Prévot, 1998). The almost 95\% failure rate that we find in our study is not exceptional for a Thellier paleointensity study, if strict pre-selection of suitable samples and strict analysis of the obtained data are made. In this study, mineralogical alteration of samples during laboratory heating can account for the unsuccessful Thellier experiments. Although our results are not numerous, some consideration is given because of good technical quality determination, attested by the reasonably high Coe et al's quality factors. These new paleointensity determinations contribute to the paleointensity database being constructed from recent studies in central Mexico (e.g., Alva-Valdivia et al., 2001; Goguitchaishvili et al., 2002; Morales et al., 2001, 2003; Urrutia-Fucugauchi et al., 2004). However, there are not enough data to discuss VDM variation trough time.

Seven sites yielded reverse polarity and 16 sites are normally magnetized. Site Cerro Grande Cortazar (Table 1) is characterized by high NRM intensity (several hundred A/m) and scattered direction probably due to the lightning. All samples from this site were rejected for further paleomagnetic analysis. An interesting feature of the geomagnetic record obtained from MGVF is that lava flow Brinco del Diablo, dated as $1.88 \pm 0.24$ Ma yielded well-defined normal paleodirections, which probably corresponds to worldwide observed Olduvai geomagnetic event within globally reverse Matuyama chron (Cande and Kent, 1995). Sites Buenavista Tomatlan and Yahuarato (Table 1) both gave similar radiometric dates $(540 \pm 80 \mathrm{ka}$ and $540 \pm 70 \mathrm{ka}$ respectively) but opposite paleodirections. Age uncertainties make difficult to affirm whether these findings represent geomagnetic phenomena. It may be speculated however that site Yahuarato records the ${ }^{40} \mathrm{Ar}-{ }^{39} \mathrm{Ar}$ dated Big Lost event (incremental heating age of 580.2 $\pm 7.8 \mathrm{ka}$ after Singer and Brown, 2002). Sites El Fresno and Cerro Grande both yielded fully reversed paleodirections. On the basis of field observations, these units are older than $40 \mathrm{ka}$ (Table 1). In absence of absolute dating, it is not clear whether they are formed during Matuyama chron or correspond to short duration geomagnetic events within Brunhes chron. 
Table 3. Summary of paleomagnetic data from volcanic rocks of Central Mexico.

\begin{tabular}{|c|c|c|c|c|c|c|c|c|c|c|}
\hline Site & Age & $N$ & Dec. $\left({ }^{\circ}\right)$ & Inc. $\left({ }^{\circ}\right)$ & $\alpha_{95}\left(^{\circ}\right)$ & $k$ & $P_{\text {lat }}$ & $P_{\text {long }}$ & Ref. & Number \\
\hline IZTA-78 & B & 7 & 1.3 & 28.3 & 3.9 & 243.2 & 85.9 & 64.3 & 1 & 1 \\
\hline IZTA-79 & B & 4 & 13.8 & 31.8 & 9.4 & 96.1 & 76.8 & 357.5 & 1 & 2 \\
\hline IZTA-80* & B & 7 & 354.6 & 33.7 & 17.4 & 13 & 84.9 & 166.6 & 1 & 3 \\
\hline IZTA-82 & B & 8 & 356.1 & 39.8 & 4.2 & 178 & 84.9 & 217.4 & 1 & 4 \\
\hline IZTA-84 & B & 7 & 355.5 & -8 & 7.2 & 70.5 & 66.6 & 93.3 & 1 & 5 \\
\hline IZTA-133 & B & 6 & 10.2 & 25.5 & 4.7 & 207.5 & 78.7 & 20.2 & 1 & 6 \\
\hline IZTA-10 & B & 6 & 7.4 & 28.5 & 4.8 & 199.3 & 82 & 19.2 & 1 & 7 \\
\hline IZTA-11 & B & 7 & 3.6 & 23.5 & 4.7 & 168.4 & 82.4 & 54.3 & 1 & 8 \\
\hline IZTA-13 & B & 7 & 355.9 & 31.5 & 2.5 & 569.1 & 85.6 & 145.9 & 1 & 9 \\
\hline IZTA-14* & B & 7 & 10.9 & 45.7 & 19.4 & 10.6 & 77.1 & 310.9 & 1 & 10 \\
\hline IZTA-16 & B & 7 & 13.4 & 38.6 & 11 & 31.2 & 77.1 & 337.3 & 1 & 11 \\
\hline IZTA-18 & B & 7 & 17.3 & 52.9 & 7.5 & 65.6 & 68.8 & 305.4 & 1 & 12 \\
\hline IZTA-19 & B & 7 & 20.6 & 51 & 10.9 & 31.7 & 67.5 & 313.6 & 1 & 13 \\
\hline IZTA-20 & B & 7 & 22.7 & 60.8 & 4.8 & 158.4 & 60.1 & 297.3 & 1 & 14 \\
\hline IZTA-21 & B & 7 & 352.4 & 32.1 & 5.3 & 131.7 & 82.6 & 160.8 & 1 & 15 \\
\hline IZTA-23 & B & 7 & 0.3 & 24.6 & 9.2 & 43.8 & 83.9 & 79.3 & 1 & 16 \\
\hline IZTA-24 & B & 7 & 355.3 & 21.3 & 6.7 & 82.4 & 80.8 & 112.3 & 1 & 17 \\
\hline IZTA-25* & B & 6 & 27 & 61.5 & 3.7 & 327.6 & 57.2 & 300 & 1 & 18 \\
\hline IZTA-26 & B & 7 & 331.9 & 24.4 & 11.3 & 29.3 & 62.3 & 163.2 & 1 & 19 \\
\hline IZTA-27 & B & 6 & 354 & 30 & 7.6 & 79.6 & 83.6 & 146.1 & 1 & 20 \\
\hline IZTA-29 & B & 7 & 7.4 & 38.1 & 7.1 & 72.6 & 82.7 & 331.6 & 1 & 21 \\
\hline IZTA-30 & B & 7 & 356.6 & 31.9 & 6.8 & 79.4 & 86.3 & 144.6 & 1 & 22 \\
\hline IZTA-31 & B & 7 & 3.8 & 35.9 & 7.6 & 64.3 & 86.3 & 337.3 & 1 & 23 \\
\hline IZTA-32 & B & 7 & 356.7 & 30 & 9.3 & 43.2 & 85.7 & 129.9 & 1 & 24 \\
\hline CHI-6 & A & 17 & 358 & 34.3 & 2.1 & 301 & 88 & 202.7 & 2 & 25 \\
\hline CHI-8 & A & 9 & 7.2 & 27.1 & 7.3 & 51 & 83.1 & 2.6 & 2 & 26 \\
\hline CHI-9 & A & 8 & 4.5 & 27.1 & 5.2 & 115 & 83.5 & 321.1 & 2 & 27 \\
\hline CHI-10 & A & 9 & 6 & 34.9 & 4.8 & 118 & 84.3 & 10.4 & 2 & 28 \\
\hline CHI-13 & A & 8 & 355.1 & 38.9 & 5.2 & 114 & 84.7 & 158.5 & 2 & 29 \\
\hline CHI-15 & A & 7 & 356.1 & 33.6 & 7.7 & 62 & 86.2 & 202.3 & 2 & 30 \\
\hline JU* & A & 7 & 323.2 & 22.4 & 3.5 & 289 & 53.8 & 164.5 & 2 & 31 \\
\hline XA & A & 5 & 343.8 & 22.1 & 4.9 & 242 & 72.6 & 146.9 & 2 & 32 \\
\hline P-2 & A & 8 & 3 & 25.7 & 7.1 & 62 & 83.6 & 287.5 & 2 & 33 \\
\hline MOE-5 & A & 8 & 346.5 & 38.3 & 5.2 & 114 & 77.1 & 183.8 & 2 & 34 \\
\hline MOE-10 & A & 6 & 356.9 & 34.9 & 7 & 92 & 87.1 & 172 & 2 & 35 \\
\hline MOE-34 & A & 7 & 352.8 & 41.8 & 2.7 & 489 & 81.7 & 208.3 & 2 & 36 \\
\hline CHII-15 & A & 11 & 345.7 & 36.3 & 2.5 & 347 & 76.5 & 177.5 & 2 & 37 \\
\hline CHI-1 & A & 8 & 357.6 & 26.7 & 6.5 & 73 & 84.5 & 253.9 & 2 & 38 \\
\hline CHI-2 & A & 14 & 6.1 & 12.9 & 2.8 & 205 & 76.2 & 304.9 & 2 & 39 \\
\hline CHI-3 & A & 12 & 330.3 & 46.6 & 1.8 & 577 & 61.5 & 165.4 & 2 & 40 \\
\hline CHI-4 & A & 9 & 342.6 & 11.6 & 4.1 & 160 & 68.6 & 224.9 & 2 & 41 \\
\hline CHI-5 & A & 11 & 345.5 & 18.6 & 4.2 & 118 & 72.9 & 221.4 & 2 & 42 \\
\hline $\mathrm{OZ}$ & A & 4 & 352.8 & 23.1 & 4.5 & 412 & 80.1 & 125.9 & 2 & 43 \\
\hline $\mathrm{ACO}$ & A & 7 & 357.6 & 32.6 & 6.7 & 82 & 87.3 & 138.5 & 2 & 44 \\
\hline MOE-28 & A & 7 & 358.5 & 33.4 & 3.8 & 253 & 88.2 & 132 & 2 & 45 \\
\hline CHI-11 & A & 12 & 16.1 & 36.1 & 2.9 & 230 & 74.8 & 14.6 & 2 & 46 \\
\hline TEU-1 & A & 7 & 338.7 & 17.1 & 4.2 & 200 & 66.9 & 147.2 & 2 & 47 \\
\hline TEU-2 & A & 5 & 358.2 & 22.4 & 7.8 & 95 & 82.3 & 93.8 & 2 & 48 \\
\hline MOE-8 & A & 6 & 352 & 23.9 & 4.5 & 219 & 79.7 & 130 & 2 & 49 \\
\hline MOE-36 & A & 7 & 346.6 & 36.1 & 6 & 101 & 77.4 & 176.9 & 2 & 50 \\
\hline MOE-24 & A & 3 & 7.8 & 21.4 & 8.9 & 192 & 78.9 & 36.8 & 2 & 51 \\
\hline MOC-55 & A & 7 & 352.7 & 18 & 7 & 76 & 77.8 & 117.1 & 2 & 52 \\
\hline MOC-56 & A & 7 & 358.3 & 35.5 & 4.9 & 153 & 88.3 & 186 & 2 & 53 \\
\hline MOE-1 & A & 8 & 353.3 & 24.1 & 5.1 & 118 & 80.6 & 125.3 & 2 & 54 \\
\hline MOE-4 & A & 5 & 23.8 & 21.5 & 9.4 & 67 & 65.6 & 7.1 & 2 & 55 \\
\hline MOE-7 & A & 9 & 353.3 & 23.7 & 8.3 & 39 & 80.5 & 124.3 & 2 & 56 \\
\hline MOE-9 & A & 7 & 10 & 17.3 & 10.3 & 36 & 75.7 & 36.9 & 2 & 57 \\
\hline MOE-11 & A & 7 & 341.8 & 27.3 & 13.1 & 22 & 71.9 & 157.8 & 2 & 58 \\
\hline MOE-12 & A & 4 & 9.3 & 17.4 & 12.2 & 58 & 76.2 & 38.9 & 2 & 59 \\
\hline MOE-13 & A & 7 & 355.7 & 17.3 & 12.6 & 24 & 78.7 & 102.9 & 2 & 60 \\
\hline MOE-14 & A & 7 & 6.7 & 24.7 & 6 & 104 & 80.9 & 34.9 & 2 & 61 \\
\hline MOE-15 & A & 8 & 354.9 & 38.8 & 2.7 & 429 & 84.6 & 199.3 & 2 & 62 \\
\hline
\end{tabular}

* Data not include in PSV analysis (see text).

(1) Steel 1985; (2) Bohnel et al. (1990); (3) Urrutia-Fucugauchi and Martin del Pozzo (1993); (4) Urrutia-Fucugauchi (1995); (5) Urrutia-Fucugauchi (1997); (6) Gonzalez et al. (1997); (7) Morales et al. (2001); (8) Bohnel and Molina-Garza (2002); (9) Conte el al. (2004); (10) This Study; (A) $<70 \mathrm{Ka}$; (B) $70 \mathrm{Ka}<\mathrm{X}<0.78 \mathrm{Ma}$; (C) $>0.78 \mathrm{Ma}$ (Matuyama). 
Table 3. (continued).

\begin{tabular}{|c|c|c|c|c|c|c|c|c|c|c|}
\hline Site & Age & $N$ & Dec. $\left({ }^{\circ}\right)$ & Inc. $\left({ }^{\circ}\right)$ & $\alpha_{95}\left(^{\circ}\right)$ & $k$ & $P_{\text {lat }}$ & $P_{\text {long }}$ & Ref. & Number \\
\hline MOE-23 & $\mathrm{A}$ & 8 & 1 & 38.5 & 3.5 & 259 & 87.5 & 282.9 & 2 & 63 \\
\hline MOE-25 & A & 5 & 352.6 & 15.4 & 7.9 & 95 & 76.4 & 113.7 & 2 & 64 \\
\hline MOE-27 & A & 10 & 1.9 & 17.6 & 9.6 & 26 & 79.5 & 70.5 & 2 & 65 \\
\hline MOE-30 & A & 5 & 14.3 & 6.1 & 11 & 50 & 68.5 & 38.5 & 2 & 66 \\
\hline MOE-31 & A & 8 & 16.2 & 25.3 & 9.2 & 37 & 73.3 & 9.8 & 2 & 67 \\
\hline MOE-32 & A & 7 & 2 & 19.1 & 12.4 & 25 & 80.2 & 69.1 & 2 & 68 \\
\hline MOE-37 & A & 8 & 338.4 & 47.8 & 10.1 & 31 & 68.2 & 200.7 & 2 & 69 \\
\hline MOE-38* & A & 6 & 46.4 & 12.2 & 8.8 & 59 & 43 & 0.8 & 2 & 70 \\
\hline MOE-39* & A & 6 & 217.8 & 7.9 & 16.5 & 22 & 46.1 & 18.9 & 2 & 71 \\
\hline MOE-41 & A & 7 & 348.9 & 32.8 & 7.8 & 61 & 79.4 & 164.3 & 2 & 72 \\
\hline MOE-43 & A & 6 & 2.8 & 35.2 & 11.9 & 33 & 87.4 & 349.7 & 2 & 73 \\
\hline MOE-44 & A & 8 & 9.7 & 35.1 & 6.4 & 77 & 80.9 & 349.44 & 2 & 74 \\
\hline MOE-45* & A & 5 & 5.9 & 18.3 & 15.6 & 24 & 78.5 & 50.3 & 2 & 75 \\
\hline CHI-12 & A & 13 & 6.4 & 15.9 & 9.2 & 21 & 77.4 & 309.6 & 2 & 76 \\
\hline $\mathrm{C} / 3$ & A & 7 & 16.8 & 21.6 & 7.2 & 71 & 72.0 & 14.4 & 3 & 77 \\
\hline $\mathrm{M} / 6$ & A & 6 & 6.0 & 32.8 & 3.0 & 513 & 84.2 & 3.1 & 3 & 78 \\
\hline IZTA-1 & B & 6 & 354.9 & 35.8 & 4.1 & 223 & 85.1 & 180.5 & 4 & 79 \\
\hline IZTA-3 & B & 7 & 347 & 38.7 & 2.7 & 502 & 77.5 & 186.1 & 4 & 80 \\
\hline IZTA-7 & B & 7 & 15.7 & 29.5 & 4.7 & 169 & 74.7 & 1.5 & 4 & 81 \\
\hline R-8 & A & 4 & I & I & 10.3 & 81 & 76.1 & 20.1 & 5 & 82 \\
\hline $\mathrm{R}-13$ & A & 5 & I & / & 12.9 & 36 & 78.3 & 232.2 & 5 & 83 \\
\hline R-14 & A & 6 & l & I & 4.3 & 246 & 80.3 & 74.5 & 5 & 84 \\
\hline$J-1$ & A & 6 & / & / & 5.5 & 150 & 80.2 & 204.5 & 5 & 85 \\
\hline $\mathrm{J}-2$ & A & 6 & I & I & 4.7 & 206 & 79.7 & 219.1 & 5 & 86 \\
\hline $\mathrm{J}-3$ & A & 6 & / & / & 8.1 & 69 & 83.2 & 203.4 & 5 & 87 \\
\hline $\mathrm{J}-4$ & A & 8 & I & I & 3.7 & 329 & 75.3 & 24.8 & 5 & 88 \\
\hline $\mathrm{J}-7$ & A & 6 & / & / & 10.5 & 29 & 85.6 & 202.8 & 5 & 89 \\
\hline $\mathrm{J}-10$ & A & 6 & / & I & 12.8 & 28 & 81.8 & 133.3 & 5 & 90 \\
\hline $\mathrm{J}-11$ & A & 7 & / & / & 12.6 & 24 & 81.6 & 25.2 & 5 & 91 \\
\hline $\mathrm{J}-12$ & A & 6 & I & I & 10.3 & 43 & 83.5 & 343.0 & 5 & 92 \\
\hline R-3 & A & 6 & / & I & 11.0 & 38 & 68.8 & 148.5 & 5 & 93 \\
\hline R-9 & A & 7 & / & I & 2.5 & 586 & 63.7 & 150.9 & 5 & 94 \\
\hline S5 & A & 7 & 353.3 & 64.4 & 3.4 & 318 & 62.2 & 250.5 & 6 & 95 \\
\hline S6 & A & 6 & 337.4 & 55.9 & 3.1 & 463 & 63.7 & 216.3 & 6 & 96 \\
\hline S7 & A & 6 & 342.6 & 16.6 & 4.2 & 255 & 70 & 140.6 & 6 & 97 \\
\hline S11 & A & 7 & 354.6 & 40.8 & 5.1 & 139 & 83.4 & 211.9 & 6 & 98 \\
\hline M2* & A & 3 & 42.2 & 10.7 & 5.3 & 540 & 46.6 & 1.4 & 6 & 99 \\
\hline JB & A & 8 & 10.4 & 17 & 3.9 & 198 & 75.6 & 35.2 & 7 & 100 \\
\hline JD & A & 8 & 13.8 & 10.8 & 3 & 353 & 70.9 & 34.4 & 7 & 101 \\
\hline $\mathrm{JE}$ & A & 8 & 4 & 23.1 & 3.3 & 277 & 82 & 51.7 & 7 & 102 \\
\hline $\mathrm{JH}$ & A & 8 & 342.7 & 21.5 & 2.9 & 371 & 71.6 & 148.3 & 7 & 103 \\
\hline $\mathrm{JJ}$ & A & 13 & 352.8 & 33 & 1.9 & 498 & 83.1 & 163.7 & 7 & 104 \\
\hline $\mathrm{JL}$ & A & 10 & 358.8 & 45 & 4.2 & 131 & 82.4 & 152.9 & 7 & 105 \\
\hline $\mathrm{JM}$ & A & 13 & 352 & 36 & 2.5 & 269 & 82.4 & 179.6 & 7 & 106 \\
\hline $\mathrm{Ceb}$ & A & 7 & 360 & 36.6 & 3.2 & 361 & 89.23 & 75.5 & 8 & 107 \\
\hline Tox & A & 26 & 345 & 34.4 & 1.8 & 248 & 75.83 & 173.56 & 8 & 108 \\
\hline Tet & A & 8 & 352.6 & 38.6 & 3.9 & 201 & 82.56 & 194.15 & 8 & 109 \\
\hline Jal & A & 8 & 7.8 & 27.8 & 3.8 & 218 & 81.1 & 25.07 & 8 & 110 \\
\hline Col & A & 23 & 1.4 & 33.7 & 9 & 12 & 88.45 & 17.64 & 8 & 111 \\
\hline Pri & A & 7 & 4.7 & 24.8 & 7.7 & 63 & 81.13 & 45.37 & 8 & 112 \\
\hline Joy & A & 3 & 356.6 & 23.2 & 5.8 & 450 & 81.82 & 107.08 & 8 & 113 \\
\hline $\mathrm{P} 1$ & B & 9 & 3.5 & 35.9 & 3.4 & 229 & 86.6 & 336.9 & 9 & 114 \\
\hline $\mathrm{P} 3 *$ & B & 5 & 324.7 & 33.1 & 4.2 & 333 & 56.6 & 175.5 & 9 & 115 \\
\hline P5 & B & 4 & 350.9 & 32.6 & 6.8 & 183 & 81.3 & 164.2 & 9 & 116 \\
\hline P7 & B & 5 & 1.2 & 6.1 & 3.2 & 591 & 74.1 & 77.3 & 9 & 117 \\
\hline P8 & B & 5 & 332.4 & 53.6 & 6.9 & 122 & 61.1 & 209 & 9 & 118 \\
\hline P10* & B & 6 & 314.4 & 52.4 & 5.7 & 137 & 47 & 200 & 9 & 119 \\
\hline P11 & B & 7 & 347.5 & 37.6 & 5 & 148 & 78.1 & 183.8 & 9 & 120 \\
\hline $\mathrm{P} 13$ & B & 8 & 344.8 & 29.8 & 3.9 & 200 & 75.2 & 162.4 & 9 & 121 \\
\hline P14 & B & 9 & 348.3 & 48.9 & 5.8 & 80 & 74.8 & 219.3 & 9 & 122 \\
\hline P15 & B & 4 & 359.6 & 27.5 & 11.3 & 67 & 85.5 & 86.4 & 9 & 123 \\
\hline P16 & B & 8 & 2.3 & 26.6 & 4.3 & 164 & 84.5 & 57.4 & 9 & 124 \\
\hline 3 & B & 6 & 331.7 & 46.2 & 6.1 & 119 & 62.8 & 194.4 & 9 & 125 \\
\hline 6 & B & 4 & 332.2 & 30.0 & 10.1 & 83 & 63.3 & 173.4 & 9 & 126 \\
\hline 9 & B & 8 & 338 & 17.8 & 6.2 & 81 & 66.5 & 193.3 & 9 & 127 \\
\hline
\end{tabular}


Table 3. (continued).

\begin{tabular}{|c|c|c|c|c|c|c|c|c|c|c|}
\hline Site & Age & $N$ & Dec. $\left({ }^{\circ}\right)$ & Inc. $\left({ }^{\circ}\right)$ & $\alpha_{95}\left(^{\circ}\right)$ & $k$ & $P_{\text {lat }}$ & $P_{\text {long }}$ & Ref. & Number \\
\hline 10 & B & 5 & 357.6 & 38.9 & 13.4 & 33 & 86.2 & 225.1 & 9 & 128 \\
\hline M-2 & B & 8 & 5.33 & 33.03 & 5.9 & 88 & 84.43 & 13.55 & 10 & 129 \\
\hline M-3 & $\mathrm{C}$ & 9 & 350.69 & 35.62 & 6.6 & 62 & 80.59 & 166.64 & 10 & 130 \\
\hline M-4* & $\mathrm{C}$ & 5 & 344.93 & 38.05 & 22.3 & 13 & 75.87 & 175.94 & 10 & 131 \\
\hline M-5 & $\mathrm{C}$ & 10 & 20.76 & 42.3 & 5.3 & 83 & 70.32 & 331.77 & 10 & 132 \\
\hline M-6 & $\mathrm{C}$ & 9 & 345.88 & 45.07 & 4.7 & 122 & 75.62 & 196.51 & 10 & 133 \\
\hline M-7 & B & 9 & 349.47 & 17.32 & 4.4 & 140 & 75.04 & 122.44 & 10 & 134 \\
\hline M-8 & A & 8 & 21.59 & 33.68 & 3.2 & 306 & 69.57 & 348.36 & 10 & 135 \\
\hline M-9 & $\mathrm{C}$ & 11 & 348.3 & 29.64 & 1.7 & 722 & 77.48 & 143.25 & 10 & 136 \\
\hline M-10 & $\mathrm{C}$ & 8 & 2.99 & 3.62 & 2.7 & 430 & 71.64 & 68.71 & 10 & 137 \\
\hline M-11 & A & 8 & 345.45 & 4.75 & 2.2 & 633 & 67.52 & 119.63 & 10 & 138 \\
\hline M-12 & B & 12 & 1.32 & 23.02 & 3.3 & 177 & 82.26 & 68.93 & 10 & 139 \\
\hline M-13 & B & 6 & 3.5 & 29.41 & 2.2 & 950 & 84.88 & 37.2 & 10 & 140 \\
\hline M-14* & A & 5 & 303.95 & 29.64 & 5.9 & 170 & 36.71 & 173.95 & 10 & 141 \\
\hline M-15 & A & 10 & 336.65 & 30.27 & 4.2 & 134 & 67.56 & 163.71 & 10 & 142 \\
\hline M-16 & A & 11 & 6.81 & 40.63 & 2.5 & 346 & 82.73 & 317.44 & 10 & 143 \\
\hline M-17 & A & 8 & 15.7 & 23.3 & 3.8 & 211 & 73.17 & 11.92 & 10 & 144 \\
\hline M-18 & A & 8 & 16.11 & 24.62 & 1.9 & 816 & 73.17 & 8.87 & 10 & 145 \\
\hline M-19* & A & 7 & 27.51 & 47.27 & 7.3 & 70 & 63.41 & 322.93 & 10 & 146 \\
\hline M-20 & B & 7 & 347.77 & 24.2 & 7.7 & 63 & 76.51 & 140.44 & 10 & 147 \\
\hline M-21 & A & 6 & 349.47 & 26.07 & 2.2 & 898 & 78.43 & 140.11 & 10 & 148 \\
\hline M-22 & A & 13 & 337.53 & 16.45 & 2.1 & 403 & 65.77 & 144.92 & 10 & 149 \\
\hline M-23 & B & 12 & 2.61 & 17.18 & 2.5 & 292 & 79.34 & 63.37 & 10 & 150 \\
\hline M-24 & A & 7 & 354.73 & 58.82 & 4.7 & 165 & 68.94 & 246.89 & 10 & 151 \\
\hline
\end{tabular}

Table 4. Angular dispersion (paleosecular variation) of the VGPs from Central Mexico.

\begin{tabular}{|c|c|c|c|c|c|c|c|c|c|}
\hline Data Set & Age & $N$ & $P_{\text {lat }}$ & $P_{\text {long }}$ & A95 $\left(^{\circ}\right)$ & $\mathrm{K}$ & $S_{F}$ & $S_{U}$ & $S_{L}$ \\
\hline Steel (1985) & $76,000-580,000$ & 24 & 86.9 & 333.2 & 5.5 & 29.6 & 14.2 & 17.6 & 11.9 \\
\hline Herrero-Bervera et al. (1986) & $0-580,000$ & 45 & 86.4 & 133.0 & 3.5 & 35.7 & 13.9 & 16.1 & 12.1 \\
\hline Bohnel et al. (1990) (Rev. Herrero et al. (1986)+new data) & Brunhes, $70 \%<40,000$ & 74 & 88.3 & 72.4 & 3.3 & 26.6 & 15.4 & 17.4 & 13.8 \\
\hline Bohnel et al. (1990)-Sel. M & Brunhes, $70 \%<40,000$ & 68 & 87.9 & 95.1 & 2.6 & 43.7 & 11.7 & 13.2 & 10.5 \\
\hline Urrutia (1997) (Rev. Bohnel et al. (1990)+new data) & Brunhes & 84 & 88.4 & 111.5 & 2.6 & 36 & 12.9 & 14.4 & 11.7 \\
\hline Urrutia (1997)-Sel. M & Brunhes & 81 & 87.8 & 106.5 & 2.4 & 43 & 11.6 & 13.0 & 10.5 \\
\hline Urrutia (1997)-Sel. V & Brunhes & 79 & 88.1 & 90.8 & 2.3 & 47 & 11.1 & 12.5 & 10.0 \\
\hline This Study & $<2,1 \mathrm{Ma}$ & 20 & 85.7 & 104.7 & 6.4 & 27.0 & 15.4 & 19.6 & 12.7 \\
\hline All published data + this study & $<70,000$ & 90 & 87.1 & 131.0 & 2.5 & 35.8 & 13.0 & 14.5 & 11.8 \\
\hline All published data+this study & $70 \mathrm{Ka}-2.1 \mathrm{Ma}$ & 48 & 87.8 & 157.7 & 3.7 & 32.7 & 13.8 & 16.0 & 12.1 \\
\hline
\end{tabular}

Sel. M-Selection using criteria of McFadden (1980). Sel. V—Selection using criteria of Vandamme (1994).

A simple way to measure the PSV is to calculate the angular standard deviation ASD of virtual geomagnetic pole for a given locally (McFadden et al., 1988, 1991). The classic formula $S_{F}^{2}=S_{T}^{2}-S_{W}^{2} / n$ was used for estimating paleosecular variation in this study where, here, $S_{T}$ is the total angular dispersion $S_{T}=\left[(1 / N-1) \sum_{i=1}^{N} \delta i^{2}\right]^{1 / 2}(\mathrm{Cox}$, 1969), $N$ the number of sites used in the calculation, $\delta_{i}$ the angular distance of the $i$ th virtual geomagnetic pole from the axial dipole, $S_{W}$ the within site dispersion and, $n$ the average number of sample per site.

Table 3 lists currently available data from volcanic rocks of central Mexico. Some of the early PSV analyses have included compilation of databases of paleodirectional results. For this study, we have re-examined the original reports to produce an updated database for central Mexico (Table 3). We use the paleolatitude of $60^{\circ}$ as a cut-off angle to separate the paleosecular variation of intermediate geomagnetic regime, and rejecting the data with $\alpha_{95}>15^{\circ}$ and $N<3$. Using this criteria and the new data obtained in this study, we obtained $S_{F}=15.4$ with $S_{U}=19.6$ and $S_{L}=12.7$ (upper and lower limits respectively) which is in good accordance with the model of McFadden et al. $(1988,1991)$ for the last $5 \mathrm{Ma}$ (Fig. 9; Table 4). Combination of our data with previously published results from TMVB do not support the hypothesis that the central Pacific low non-dipole region extends westwards into central Mexico as suggested by Doell and Cox (1971).

Paleomagnetic investigations of PSV in the Pacific volcanic sequences (e.g., Tanaka and Kono, 1991; Mankinen and Champion, 1993; Miki et al., 1998) have obtained data supporting the existence of a significant non-dipole field at the central Pacific Ocean region. Johnson and Constable (1998) have proposed the occurrence of large non-axial dipolar contributions over time scales of 100 years to 1 Ma in the Pacific region. On the other hand, McElhinny and McFadden (1997) have re-examined the old data from Hawaii and Tahiti and used a new statistical method to account of those flows that have repeatedly sampled the same 




Fig. 9. Estimate of total angular dispersion (PSV) for the paleodirectional data from MGVF plotted in the diagram of paleosecular variation of lavas (PSVL) for the last $5 \mathrm{Ma}$ (PSV model diagram modified from McFadden et al. $(1988,1991)$.

geomagnetic field vector. They concluded that the amplitude of the secular variation is consistent with values from other worldwide-scattered sites, not supporting the hypothesis of the Pacific low non-dipole window (see also McElhinny et al., 1996).

The occurrence of significant non-dipole field anomalies and the time-averaged field have long remained central aspects of paleomagnetic research (Wilson, 1970; Wilson and McElhinny, 1974). Temporal average of paleomagnetic directions for a given locality should permit to average out the secular variation effects, and the time-averaged paleomagnetic field is then the geocentric axial dipole field. This constitutes the geocentric axial dipole GAD hypothesis, which provides the foundations for tectonic applications of paleomagnetism. Wilson (1970) found that paleomagnetic directions averaged over long intervals in the Tertiary often result in shallower inclinations compared to those for a GAD field. This inclination anomaly has been thoroughly studied and several models have been developed to explain its spatial and temporal characteristics (Wilson and McElhinny, 1974; McFadden et al., 1988, 1991). Elmaleh et al. (2001) have proposed that an inclination anomaly of about $-10^{\circ}$ has characterized the Pacific Ocean region during Brunhes chron. The inclination anomaly is asymmetrically distributed with respect to the magnetic equator, which has been related to offset dipolar fields, and axial quadrupole and octupole effects. The paleomagnetic mean direction for the Michoacán-Guanajuato volcanics shows an inclination anomaly of only few degrees, indicating no significant anomaly for central Mexico. The absence of significant inclination anomalies for central Mexico has also been documented in other studies of Plio-Quaternary volcanic sequences (e.g., Urrutia-Fucugauchi, 1996; Goguitchaichvili et al., 2002; Bohnel and Molina-Garza, 2002). For Tertiary times, tectonic deformation makes inferences about the time-averaged paleofield more problematic.
Acknowledgments. We thank Prof. Herve Guillou for the K/Ar studies of the Michoacan-Guanajuato volcanic field. We gratefully acknowledge critical comments provided by B. Henry and an anonymous reviewer. Partial economic support for this project has been provided by UNAM-DGAPA grant IN100403 and CONACYT project no. 42661

\section{References}

Alva-Valdivia, L., A. Goguitchaichvili, J. Urrutia-Fucugauchi, and J. Morales, Further constraints for the Pliocene geomagnetic field strength: New results from the Los Tuxtla volcanic field (Mexico), Earth Planets Space, 53, 873-881, 2001.

Ban, M., T. Hasenaka, H. Delgado-Granados, and N. Takaoka, K-Ar ages of lavas from shield volcanoes in the Michoacan-Guanajuato volcanic field, Mexico, Geofisica International, 31, 467-473, 1992.

Besse J. and V. Courtillot, Apparent true polar wander and the geometry of the geomagnetic field over the last $200 \mathrm{Ma}$., J. Geophys. Res, 107, 2300, doi:10.1029/2000JB000050, 2002 .

Bohnel, H. and R. Molina-Garza, Secular variation in Mexico during the last 40,000 years, Phys. Earth Planet. Inter., 133, 99-109, 2002.

Bohnel, H., J. Urrutia-Fucugauchi, and E. Herrero-Bervera, Paleomagnetic data from central Mexico and their use for paleosecular variation studies, Phys. Earth Planet. Inter., 64, 224-236, 1990.

Campos-Enriquez, J. J., J. O. Campos-Enriquez, and J. UrrutiaFucugauchi, Variación secular reciente y cartas de los elementos del campo geomagnético en Mexico, Geofisica Internacional, 30, 107-116, 1991

Cande, S. C. and D. V. Kent, Revised calibration of the geomagnetic polarity time scale for the Late Cretaceous and Cenozoic, J. Geophys. Res., 100, 6093-6095, 1995.

Coe, R., The determination of paleo intensities of the Earth's field with emphasis on mechanism which could cause non-ideal behavior in Thellier's method, J. Geomagn. Geolectr., 19, 157-179, 1967.

Coe, R., S. Gromme, and E. A. Mankinen, Geomagnetic paleointensity from radiocarbon-dated lava flows on Hawaii and the question of the Pacific non-dipole Low, J. Geophys. Res., 83, 1740-1756, 1978.

Conte, G., J. Urrutia-Fucugauchi, A. Goguitchaichvili, A. M. SolerArechalde, O. Morton-Bermea, and A. Incoronato, Paleomagnetic study of lavas from the Popocatepetl volcanic region, Central Mexico, International Geology Review, 46, 210-225, 2004.

Cox, A., Confidence limits for the precision parameter k, Geophys. J. R astr. Soc., 17, 545-549, 1969.

Day, R., M. Fuller, and V. A. Schmidt, Hysteresis properties of titanomagnetites: Grain size and compositional dependence, Phys. Earth. Planet Inter., 13, 260-267, 1977.

Doell, R. and A. Cox, Pacific geomagnetic secular variation, Science, 71 248-254, 1971

Doell, R. and A. Cox, The Pacific geomagnetic secular variation anomaly and the question of lateral uniformity in the lower mantle, in The Nature of the Solid Earth, edited by E. C. Robertson, McGraw-Hill, New York, pp. 245-284, 1972.

Delgado-Granados, H., J. Urrutia-Fucugauchi, T. Hasenaka, and M. Ban, Southward volcanic migration in the western Trans-Mexican Volcanic Belt during the last 2 Ma, Geofis. Int., 34, 341-352, 1995.

Dunlop, D. J., Theory and application of the Day plot (Mrs/Ms versus $\mathrm{Hcr} / \mathrm{Hc}$ ) 1: Theoretical curves and tests using titanomagnetite data, J.Geophys. Res., 107(B3), 10.1029/2001JB000486, 2002

Dunlop, D. J. and O. Ozdemir, Rock-Magnetism Fundamentals and Frontiers, Cambridge, UK, Cambridge University Press, pp. 573, 1997.

Elmaleh, A., J.-P. Valet, and E. Herrero-Bervera, A map of the Pacific geomagnetic anomaly during the Brunhes chron, Earth Planet. Sci. Lett., 193, 315-332, 2001.

Fisher, R. A., Dispersion on the sphere, Proc. R. Soc. Lond. Ser., A217, 295-305, 1953.

Goguitchaichvili, A., M. Prevot, and P. Camps, No evidence for strong fields during R3-N3 Icelandic geomagnetic reversals, Earth Planet. Sci. Lett., 167, 15-34, 1999.

Goguitchaichvili, A., A. Chauvin, P. Roperch, M. Prevot, M. Vergara, and H. Moreno, Paleomagnetism of the Miocene Farellones Formation in Chile, Geophys. J. Int., 140, 357-374, 2000.

Goguitchaichvili, A., P. Camps, and J. Urrutia-Fucugauchi, On the features of the geodynamo following reversals and excursions: by absolute geomagnetic intensity data, Phys. Earth Planet. Inter., 124, 81-93, 2001.

Goguitchaichvili, A., L. Alva-Valdivia, J. Rosas-Elguera, J. UrrutiaFucugauchi, J. Gonzalez, J. Morales, and J. Solé, An integrated pale- 
omagnetic study of Rio Grande de Santiago volcanic succession (TransMexican volcanic belt): revisited, Phys. Earth Planet. Inter., 130, 175194, 2002.

Gonzalez, S., G. Sherwood, H. Bohnel, and E. Schnepp, Paleosecular variation in Central Mexico over last 30,000 years: the record from lavas, Geophys. J. Int., 130, 201-219, 1997.

Hasenaka, T., Size, distribution, and magma output rate for shield volcanoes of the Michoacan-Guanajuato volcanic field, Central Mexico, $J$. Volcanol. Geotherm. Res., 63, 13-31, 1994.

Hasenaka, T. and I. S. E. Carmichael, A compilation of location, size, and geomorphological parameters of volcanoes of the MichoacanGuanajuato volcanic field, central Mexico, Geofisica Internacional, 24(4), 577-607, 1985.

Hasenaka, T. and I. S. E. Carmichael, The cinder cones of MichoacanGuanajuato, central Mexico: petrology and chemistry, J. Petrol., 28, 241-269, 1987.

Hasenaka, T., M. Ban, and H. Delgado-Granados, Contrasting volcanism in the Michoacan-Guanajuato Volcanic Field, central México: Shield volcanoes vs. cinder cones, Geofisica Internacional, 33, 125-138, 1994.

Herrero-Bervera, E., J. Urrutia-Fucugauchi, A. Martin del Pozzo, H. Bohnel, and J. Guerrero, Normal amplitude Brunhes paleosecular variation at low-latitudes: A paleomagnetic record from the Trans-Mexican Volcanic Belt, Geophys. Res. Lett., 13, 1442-1445, 1986.

Johnson, C. L and C. G. Constable, Persistently anomalous Pacific geomagnetic fields, Geophys. Res. Lett., 25, 1011-1014, 1998.

Juarez, M. T., L. Tauxe, J. S. Gee, and T. Pick, The intensity of the Earth's magnetic field over the past 160 million years, Nature, 394, 878-881, 1998.

Kirschvink, J. L., The least-squares line and plane and the analysis of palaeomagnetic data, Geophys. J. R. Astr. Soc., 62, 699-718, 1980.

Kosterov, A. and M. Prévot, Possible mechanisms causing failure of Thellier paleointensity experiments: results of rock-magnetic study of the Lesotho basalt, Southern Africa, Geophys. J. Int., 134, 554-572, 1998.

Love, J. J., Palaeomagnetic secular variation as a function of intensity, Phil. Trans R. Soc., 358, 1191-1223, 2000.

Mankinen, E. A. and D. E. Champion, Latest Pleistocene and Holocene geomagnetic intensity on Hawaii, J. Geophys. Res., 262, 412-423, 1993.

McElhinny, M. W. and P. L. McFadden, Paleosecular variation over the past 5 Myr based on a new generalized database, Geophys. J. Int., 131, 240-252, 1997.

McElhinny, M. W., P. L. McFadden, and R. Merrill, The myth of the Pacific dipole window, Earth Planet Sci. Lett., 143, 13-22, 1996.

McFadden, P. L., Determination of the angle in a Fisher distribution which will be exceeded with a given probability, Geophys. J. R. astr. Soc., 60, 391-396, 1980.

McFadden, P., T. Merrill, and W. McElhinny, Dipole/quadrupole family modeling of paleosecular variation, J. Geophys. Res., 93, 11583-11588, 1988.

McFadden P. L., R. Merrill, M. W. McEllhinny, and S. Lee, Reversals of the Earth's magnetic field and temporal variations of the dynamo families, J. Geophys. Res., 96, 3923-3933, 1991.

McWilliams, M., R. Holcomb, and D. Champion, Geomagnetic secular variation from ${ }^{14} \mathrm{C}$ dated lava flows on Hawaii and the question of the Pacific non-dipole low, Phil. Trans. R. Soc. Lond., A306, 211-222, 1982.

Miki, M., H. Inokuchi, S. Yamaguchi, J. Matsuda, K. Nagao, N. Isezaki, and K. Yasakawa, Geomagnetic paleosecular variation in Easter Island, the southeast Pacific, Phys. Earth. Planet. Int., 106, 93-101, 1998.

Molnar, P. and L. R. Sykes, Tectonics of the Caribbean and Middle America regions from focal mechanisms and seismicity, G. S. A. Bulletin, 80, 1639-1684, 1969.

Morales, J., A. Goguitchaichvili, and J. Urrutia-Fucugauchi, A rockmagnetic and paleointensity study of some Mexican volcanic lava flows during the Latest Pleistocene to the Holocene, Earth Planets Space, 53, 839-902, 2001.

Morales, J., A. Goguitchaichvili, L. Alva-Valdiva, N. Gratton, J. UrrutiaFucugauchi, J. Rosas-Elguera, and A. Soler-Arechalde, An attempt to determine the microwave paleointensity on historic Paricutin volcano lava flows, Central Mexico, Geofisica Internacional, 42(1), 95-100, 2003.

Nagata, T., R. M. Fisher, and K. Momose, Secular variation of the geomagnetic total force during the last 5000 years, J. Geophys. Res., 68 , 5277-5281, 1963.
Nixon, G. T., A. Demant, R. L. Armstrong, and J. E. Harakal, K-Ar and geologic data bearing on the age and evolution of the Trans-Mexican Volcanic Belt, Geofisica Internacional, 26, 109-158, 1987.

Prévot, M., R. S. Mankinen, S. Gromme, and A. Leccaille, High paleointensity of the geomagnetic field from thermomagnetic studies on rift valley pillow basalts from the middle Atlantic ridge, J. Geophys. Res., 88, 2316-2326, 1983.

Riisager, J., M. Perrin, P. Riisager, and G. Ruffet, Paleomagnetism, paleointensity and geochronology of Miocene basalts and baked sediments from Velay Oriental, French Massif Central, J. Geophys. Res., 105, 883896, 2000.

Riisager, P., J. Riisager, N. Abrahamsen, and R. Waagstein, Thellier paleointensity experiments on Faroes flood basalts: Technical aspects and geomagnetic implications, Phys. Earth. Planet. Inter., 113, 91-100, 2002.

Selkin, P. A. and L. Tauxe, Long-term variations in palaeointensity, Philos. Trans. R. Soc. London, A358, 1065-1088, 2000.

Singer, B. S. and L. L. Brown, The Santa Rosa Event: ${ }^{40} \mathrm{Ar} /{ }^{39} \mathrm{Ar}$ and paleomagnetic results from the Valles rhyolite near Jaramillo Creek, Jemez Mountains, New Mexico, Earth Planet. Sci. Lett., 197, 51-64, 2002.

Steele, K. W., Paleomagnetic constraints on the volcanic history of Iztaccihuatl, Geofisica Internacional, 24, 159-167, 1985.

Tanaka, H. and M. Kono, Preliminary results and reliability studies on historical and radiocarbon dated Hawaiian lavas, J. Geomag. Geoelectr., 43, 375-388, 1991.

Tauxe, L., Sedimentary records of relative paleointensities: Theory and Practice, Rev. Geophys., 31, 319-354, 1993.

Tauxe, L., T. A. T. Mullender, and T. Pick, Pot-bellies, wasp-waists and superparamagnetismo in magnetic hysteresis, J. Geophys. Res., 95, 12337-12350, 1996.

Thellier, E. and O. Thellier, Sur l'intensite de champ magnetique terrestre dans le passe historique et geologique, Ann. Geophys, 15, 285-376, 1959.

U.S.-Japan Paleomagnetic Cooperation Program in Micronesia, Paleosecular variation of lavas from the Marianas in the Western Pacific Ocean, J. Geomag. Geolectr., 27, 57-66, 1975.

Urrutia-Fucugauchi, J., Constraints on Brunhes low-latitude paleosecular variation-Iztaccíhuatl stratovolcano, basin of Mexico, Geofisica Internacional, 34, 253-262, 1995.

Urrutia-Fucugauchi, J., Palaeomagnetic Study of the Xitle-Pedregal Flow, southern Basin of Mexico, Phys. Earth Planet Inter., 97, 177-196, 1996.

Urrutia-Fucugauchi, J., Comments on A new method to determine paleosecular variation, Phys. Earth. Planet. Inter., 102, 295-300, 1997.

Urrutia-Fucugauchi, J. and A. Martin del Pozzo, Implicaciones de los datos paleomagneticos sobre la edad de la Sierra de Chichinautzin, cuenca de Mexico, Geofisica Internacional, 32, 523-533, 1993.

Urrutia-Fucugauchi, J. and L. del Castillo, Un modelo del Eje Volcanico Mexicano, Bol. Soc. Geol. Mexicana, 38, 18-28, 1977.

Urrutia-Fucugauchi, J. and O. Campos-Enriquez, Geomagnetic secular variation in Central Mexico since 1923 AD and comparison with 19451990 IGRF models, J. Geomagn. Geoelectr., 45, 243-249, 1993.

Urrutia-Fucugauchi, J., L. Alva-Valdivia, A. Goguitchaichvili, M. L. Rivas, and J. Morales, Palaeomagnetic, rock-magnetic and microscopy studies of historic lava flows from Paricutin volcano, Mexico: Implications for the deflection of palaeomagnetic measurements, Geophys. J. Int., 156, 431-442, 2004.

Vandamme D., A new method to determine paleosecular variation, Phys. Earth. Planet. Inter., 85, 131-142, 1994.

Wilson, R. L., Permanent aspects of the Earth's non-dipole magnetic field over upper Tertiary times, Geophys. J. R. astr. Soc., 19, 417-437, 1970.

Wilson, R. L. and M. W. McElhinny, Investigation of the large scale palaeomagnetic field over the past 25 million years. Eastward shift of the Icelandic spreading ridge, Geophys. J. R. astr. Soc., 39, 570-586, 1974.

Zijderveld, J. D. A., A. C. demagnetization of rocks: analysis of results, in Methods in Palaeomagnetism, edited by D. W. Collinson, K. M. Creer, and S. K. Runcorn, Elsevier, Amsterdam, pp. 254-286, 1967.

G. Conte-Fasano (e-mail: gennaro@geofisica.unam.mx), J. UrrutiaFucugauchi, A. Goguitchaichvili, and J. Morales-Contreras 